DOI 10.26886/2414-634X.5(24)2018.4

UDC 658.6

\title{
METHODOLOGICAL ASPECTS OF FORMATION MARKET OFFERS OF HIGHER EDUCATION
}

\section{O. Deineha, PhD in Economical Sciences}

Rivne State Humanitarian University, Ukraine, Rivne

In the conditions of globalization, internationalization, informatization of the world economy, as well as the reduction of the aging period, educational organizations must dynamically and systematically update their market offer. The purpose of the publication is to concretize and substantiate the practical and theoretical approaches to the formation of a market offer by higher education institutions. To adequately and fully meet the needs of target markets, an educational organization can apply such forms of sales policy implementation as modernization, updating, modification and diversification of the range of services. The active use of information technology in educational activities contributes to the expansion, updating of the range of services, as well as the growth of target markets of educational organization and their capacity.

Key words: educational organization, educational service, assortment, nomenclature, information technologies, modernization, updating, modification, diversification.

кандидат економічних наук, Дейнега І. О. Методичні аспекти формування ринкової пропозиції закладами вищої освіти / Рівненський державний гуманітарний університет, Україна, Рівне

В умовах глобалізації, інтернаціоналізації, інформатизації світової економіки, а також зниження періоду старіння знань, освітні організації повинні динамічно та системно оновлювати свою ринкову пропозицію. Метою публікації $є$ конкретизація й обгрунтування 
практичних та теоретичних підходів щодо фрормування ринкової пропозиції закладами вищої освіти. Для адекватного та повного задоволення потреб цільових ринків освітня організація може застосовувати такі фоорми реалізації асортиментної політики як модернізація, оновлення, модифрікація та диверсифрікація асортименту послуг. Активне використання інформаційних технологій в освітній діяльності сприяє розширенню, осучасненню асортименту послуг, а також нарощенню цільових ринків освітньої організації та їх місткості.

Ключові слова: освітня організація, освітня послуга, асортимент, номенклатура, інфрормаційні технології, модернізація, оновлення, модифрікація, диверсифікація.

Постановка проблеми. Наявність збалансованої ринково орієнтованої пропозиції організацій є базовим фактором забезпечення їх конкурентоздатності, адже саме максимальне врахування ринкових потреб дозволить їм забезпечити вагомі конкуренті переваги на ринку. Ця теза властива всім без винятку організаціям, що орієнтовані на задоволення потреб споживача, в тому числі і закладам вищої освіти (3ВО). Науково-технічний прогрес, особливо динамічний з точки зору розвитку інформаційних технології, поступово трансформує навчальні та комунікаційні процеси організації. Застосування інфрормаційних систем при наданні освітніх послуг істотно впливає на зміну ринкових стандартів якості цих послуг, зокрема з позиції доступності чи тривалості надання, а також дозволяє розширити та осучаснити як ринкову пропозицію освітніх організацій, так і збільшити кількість цільових ринків, що ними обслуговуються. Глобальна інформатизація суспільства накладає також відбиток і на професійні компетенції випускників 3ВО, що вимагає від них постійного корегування освітніх 
програм з метою їх осучаснення та пристосування до актуальних вимог ринку праці. За таких умов назрілим $є$ визначення базових методичних підходів до формування ринкової пропозиції освітньої організації.

Аналіз останніх досліджень і публікацій. Дослідженню асортиментної політики підприємств присвячена значна кількість навчальної та наукової літератури. Теоретичні основи фрормування та реалізації асортиментної політики підприємств в контексті дослідження інших питань розглядали В. Кардаш, С. Ковальчук, Є. Крикавський, С. Ілляшенко, М. Окландер, Н. Чухрай та інші. Окремі проблеми практичної реалізації асортиментної політики в системі управління господарською діяльністю підприємств розкрито у роботах С. Гаркавенко, О. Дейнеги, О.Мних, Г. Холодного тощо.

Проте вивчення питань, пов'язаних із формуванням ринкової пропозиції освітніх організацій, $€$ не надто популярним. Такими дослідженнями займались О. Кратт [1; 2], О. Хоменко [3], С. Тєлєтова, О. Тєлєтов [4]. Одночасно залишаються не повністю з'ясованими питання стосовно структурування освітньої пропозиції та адаптування традиційних форм управління асортиментом до специфіки освітньої діяльності.

Цілі статті. Метою написання публікації $є$ конкретизація й обгрунтування практичних та теоретичних підходів щодо фрормування освітньої пропозиції ЗВО.

Результати дослідження. В сучасній українській літературі 3 маркетингу відсутнє однозначне тлумачення широковживаних понять „товарний асортимент” та „товарна номенклатура”. Найчастіше ці поняття вживаються як слова-синоніми. Різні літературні джерела так визначають суть цих понять:

-асортимент (із фр. assortiment, від assorti - підібраний)- набір товарів або виробів різних видів і сортів; взагалі різноманітний набір 
чого-небудь [5, с. 26]; склад однорідної продукції за видами, сортами, марками [6, с. 49]; група товарів, тісно пов'язаних між собою або через подібність у функціонуванні, або через те, що їх продають одним й тим групам клієнтів, або через одні й ті ж типи торгових закладів, або в рамках одного й того ж діапазону цін [7, с. 310].

•номенклатура (із лат. розпис імен)- сукупність назв продукції, що виробляється [5, с. 625]; сукупність всіх асортиментних груп товарів і товарних одиниць, що пропонуються покупцям конкретним продавцем [7, c. 313].

Проведене семантичне співставлення дає змогу стверджувати, що:

- товарний асортимент - це набір однорідних товарів, що пропонується підприємством-виробником (збутовим підприємством) на ринку;

- товарна номенклатура - це сукупність всіх асортиментних груп товарів і товарних одиниць, що пропонуються підприємством на ринку.

Отже, якщо діяльність підприємства не диверсифікована і воно здійснює свою виробничу, збутову діяльність вузько спеціалізовано (наприклад, випускає або реалізовує однорідні товари), то в даному випадку доцільно говорити про „товарний асортимент”. В іншому разі, правильно вживати поняття „товарна номенклатура” [8, с. 33].

По відношенню до освітніх організацій ці дефрініції можна тлумачити наступним чином: якщо освітня організація здійснює виключно освітню діяльність, то види освітніх послуг, які вона продукує, будуть формувати асортимент послуг, а у випадку, якщо така організація здійснює диверсифіковану діяльність, в сферу інтересів якої додатково включаються науково-дослідна, поліграфрічна, мистецька тощо діяльність, то мова йде про номенклатуру.

По відношенню до асортименту послуг можна виділити такі ж фрорми реалізації, як і по відношенню до матеріальних товарів: 
модернізація або осучаснення, оновлення, модифікація та диверсифрікація.

Модернізація асортименту послуг буде передбачати таку зміну вже існуючих в асортименті послуг, яка б повністю відповідала вимогам науково-технічного прогресу. По відношенню до освітніх послуг вона може передбачати застосування комп'ютерних та он-лайн технологій для забезпечення навчального процесу, зокрема впровадження дистанційної форми навчання як в доповнення до традиційних стаціонарних фоорм проведення занять, так і для автономного ії використання.

Оновлення асортименту освітніх послуг забезпечує заміну не актуальних кваліфікацій на нові, що користуються попитом на ринку праці, причому модернізації форм навчання при цьому не відбувається.

Під модифрікацією освітньої послуги в першу чергу розуміється розширення кількості спеціалізацій визначеної спеціальності в межах розробленої освітньо-професійної програми (наприклад, відкриття в межах спеціальності 073 «Менеджмент» спеціалізацій «Адміністративний менеджмент», «Бізнес-адміністрування», «Логістика», «Менеджмент зовнішньоекономічної діяльності», «Управління навчальним закладом», «Управління фрінансовоекономічною безпекою» тощо).

Диверсифікація асортименту освітньої організації передбачає насамперед вихід за межі її основної діяльності, тобто діяльності по наданню освітніх послуг. В такому випадку мова йде про фрормування номенклатури послуг, коли поруч із освітніми ЗВО надає поліграфрічні, консультаційні, дослідницькі тощо послуги.

Асортимент освітніх послуг традиційно складається із видів освітніх послуг, які, в свою чергу, поділяються на асортиментні позиції. В основі диференціації послуг, наданих вищою школою, науковці 
пропонують враховувати такі фрактори: 1) пропоновані програми (підготовка бакалаврів, магістрів, аспірантів); 2) галузева спрямованість (економіка, менеджмент, гуманітарні чи технічні науки, галузі промисловості, сільського господарства і т.д.); 3) використовувані технології навчання (дистанційне, у малих групах, індивідуальне, використання сучасних технічних засобів і т.д.) [3, с. 36].

В укрупненому вигляді послуги ЗВО прийнято поділяти на види за формою здобуття освіти та спеціальностями (спеціалізацією). Асортиментною позицією в ЗВО є, наприклад, освітня послуга по підготовці бакалавра з логістики денної фформи навчання. В освітній діяльності її прийнято називати освітнім продуктом, який розглядають як «спеціальний інтелектуальний продукт, адаптований до відповідного сегменту освітніх послуг» [4, с. 119].

Для більшості вітчизняних ЗВО найбільш характерними є очна (денна, вечірня) і заочна форми навчання. Реалізація ЗВО інших форм передачі знань могла б значно розширити їх асортимент послуг та забезпечити максимальне задоволення потреб споживачів.

Уже сьогодні вітчизняна вища освіта пережила ряд необхідних трансформацій. Про це свідчить, на думку О. Кратта, те, що останні роки «успішно нівелюється зайва професійна спеціалізація на бакалаврському рівні. Відбувається трансформація асортименту послуг вищої освіти у напрямку скорочення програм підготовки» [1, с. 97-98]. Крім того, розширенню та модернізації асортименту освітніх послуг сприяє налагодження плідної міжнародної співпраці вітчизняних 3ВО із їх закордонними колегами. Як вважає О. Воробйова, «інтернаціоналізація та збільшення кількості міжнародних обмінів, що спонукає до фрормування єдиного міжнародного простору 3 урахуванням економічної, політичної і культурної інтеграції» $€$ ознакою глобалізації [9]. За таких умов успішно реалізується практика 
«подвійних дипломів», коли здобувач одночасно навчається в одному українському та одному закордонному ЗВО і за результатами навчання отримує два дипломи. Проте варто відзначити, що підготовка бакалаврів в Україні є найтривалішою - чотири роки на противагу практиці європейських країн, де підготовка спеціаліста такого рівня здійснюється переважно за три роки. Така часова характеристика погіршує їх шанси на ефективну адаптацію на ринку праці. Особливо це актуально для спеціальностей, здобувачі яких в подальшому будуть здійснювати свою діяльність у реальному секторі економіки країни, адже ринкові процеси настільки стохастичні і мінливі, що за такий значний період необхідна на ринку тепер спеціальність може стати не актуальною.

О. Кратт справедливо вирізняє такі основні властивості асортименту освітніх послуг як різноманіття та динаміка [2, с. 79], наголошуючи таким чином на постійних змінах в ньому відповідно до ринкових потреб. Суттєвою особливістю сучасного ринку освітніх послуг $€$ впровадження такої фрорми передачі знань як дистанційне навчання. Вона вважається однією з найбільш перспективних форм розвитку асортиментної політики ЗВО, бо дозволяє здобувачу отримати бажану освіту, не виходячи з дому.

Дистанційне навчання з використанням он-лайн технологій робить освітні послуги більш доступними і відкриває нові перспективи як для споживачів, так і для продавців. За допомогою дистанційної освіти у ЗВО з'являється можливість виходу на нові цільові ринки, насамперед міжнародний та освіти для дорослих. У розвинених країнах світу дистанційне навчання 3 використанням он-лайн технологій стало основою функціонування інфрормаційного суспільства, без якого важко уявити процеси навчання сьогодні. 
Інформаційне суспільство - це новий тип суспільства, особливістю якого $є$ підвищена цінність інформації як базового ресурсу людства. Оскільки одним із секторів, що займається обробкою інформації є освіта, то на неї сьогодні покладаються надзвичайно важливі функції по генеруванню, акумулюванню, передачі знань, яких на даному етапі найбільше потребує суспільство.

Отримані під час навчання у ЗВО знання сьогодні швидко старіють, тому на освітні організації покладається додаткова функція постійного осучаснення знань уже працюючого населення. Задовольнити потребу в нових знаннях без відриву від виробництва може дистанційна освіта. Такий формат передачі інформації як лекції, практичні або семінарські заняття в аудиторії поступово замінюються іншими. На їх місце приходять нові технології навчання, в основі яких лежать он-лайн технології. Перевагою такого навчання $€$ також те, що при правильній організації навчального матеріалу $\epsilon$ можливість швидко його адаптувати до змін навколишнього середовища.

Підсумовуючи всі попередні розмірковування, можемо виокремити такі основні фактори впливу на асортимент 3ВО (рис. 1).

Таким чином, асортимент послуг ЗВО будуть впливати як внутрішні можливості, так і зовнішні обмеження та перспективи. Найбільш пріоритетними $є$ саме потреби потенційних та реальних здобувачів вищої освіти, а також інших стейкхолдерів ЗВО.

Висновки. На діяльність освітніх організацій покладається важлива місія передачі нових знань, необхідних для вирішення завдань реального сектору економіки. Враховуючи глобалізацію, інтернаціоналізацію, інформатизацію світової економіки, а також зменшення лагу старіння знань, освітні організації повинні динамічно оновлювати свою ринкову пропозицію, пристосовуючи ії як до мінливих 
вимог міжнародного та національного ринків, так і до такого нового сегменту ринку як «освіта для дорослих».

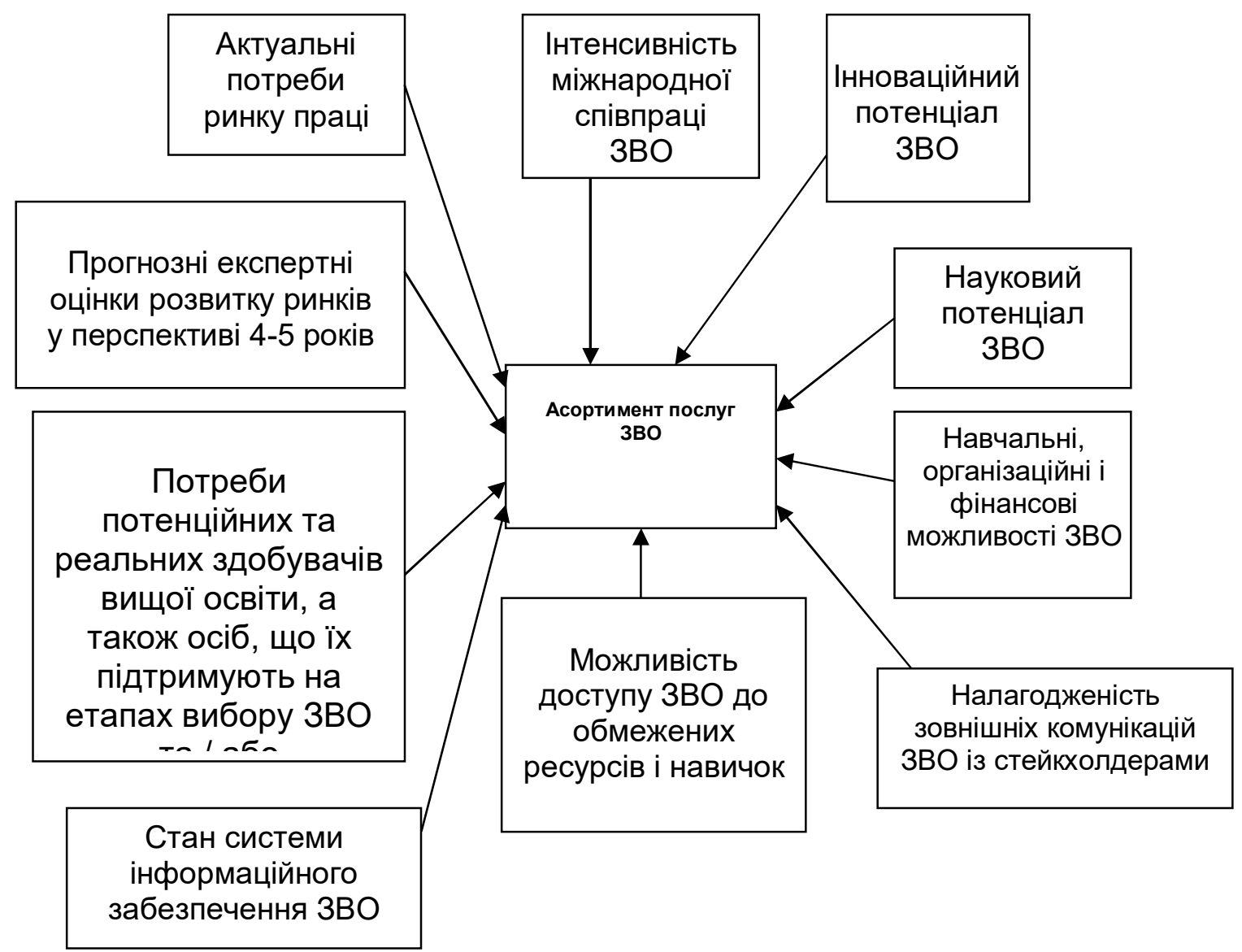

Рис. 1. Фактори впливу на асортимент послуг 3ВО

3 метою адекватного і повного задоволення потреб всіх своїх цільових ринків освітня організація може застосовувати такі фрорми реалізації асортиментної політики як модернізація, оновлення, модифікація та диверсифікація асортименту освітніх послуг. Підвищити якість освітніх послуг та отримати доступ до нових сегментів ринку можна за допомогою дистанційної освіти з використанням он-лайн технологій.

\section{תimepamypa:}


1. Кратт О. А. Асортимент послуг вищої освіти: вітчизняні та зарубіжні реалії / О. А. Кратт // Економіка та підприємництво: зб. наук. пр. молодих учених та аспірантів: у 2 ч. / M-во освіти і науки України, ДВНЗ «Київ. нац. екон. ун-т ім. Вадима Гетьмана»; редкол.: С. І. Дем'яненко (відп. ред.) [та ін.]. - Київ: КНЕУ, 2015. - Вип. 34-35, ч. 1. - C. 88-99.

2. Кратт О. А. Ринок послуг вищої школи: методологічні основи дослідження кон'юнктури: монографрія/ О. А. Кратт. - Донецьк: ТОВ «Юго-Восток, Лтд», 2003. - 360 c.

3. Хоменко О. Особливості маркетингового ціноутворення на ринку освітніх послуг / О. Хоменко // Вісник Київського національного університету технологій та дизайну. Серія "Економіка і вища ocвima". - 2015. - № 5 (91). - C. 34-39.

4. Тєлєтова С. Г. Педагогічний маркетинг у діяльності навчальних закладів / Тєлєтова С. Г., Тєлєтов О. С. // Маркетинг і менеджмент інновацій. - 2011. - № 3, T. 2. - С. 117-124.

5. Великий тлумачний словник сучасної української мови / Уклад. і голов. ред. В. Т. Бусел. - К.: Ірпінь: ВТФ „Перун”, 2003. - 1440 с.

6. Статистика рынка товаров и услуг: Учебник. - 2-е изд. пераб. и доп./ И. К. Беляевский, Г. Д. Кулагина, Л. А. Данченок и др.; Под ред. И. К. Беляевского. - М.: Финансы и статистика, 2002.-656 с.

7. Котлер, Ф. Основы маркетинга: Пер. с англ./ Общ. ред. и вступ. cm. Е. М. Пеньковой.- М.: Прогресс, 1990.-736 с.

8. Дейнега О. В. До питання про генезис основних дефрініцій із маркетингової товарної політики / О. В. Дейнега, І. О. Дейнега // Вісник національного університету "Львівська політехніка". Серія: «Логістика». - 2004. - № 499. - С. 31-36.

9. Vorobyova $O$. The influence of globalization processes on higher education development [Електронний ресурс]/ O. Vorobyova // Innovative 
solutions in modern science. - 2018. - № 2(21). - С. 74-85. - Режим доступу:

http://naukajournal.org/index.php/ISMSD/article/view/1477/1561

\section{References:}

1. Kratt O. A. Asortyment posluh vyshchoyi osvity: vitchyznyani ta zarubizhni realiyi/ O. A. Kratt // Ekonomika ta pidpryyemnytstvo: zb. nauk. pr. molodykh uchenykh ta aspirantiv: u 2 ch. / M-vo osvity i nauky Ukrayiny, DVNZ «Kyyiv. nats. ekon. un-t im. Vadyma Het'mana»; redkol.: S. I. Dem"yanenko (vidp. red.) [ta in.]. - Kyyiv: KNEU, 2015. - Vyp. 34-35, ch. 1. - S. 88-99.

2. Kratt O. A. Rynok posluh vyshchoyi shkoly: metodolohichni osnovy doslidzhennya kon"yunktury: monohrafiya/ O. A. Kratt. - Donets'k: TOV «Yuho-Vostok, Ltd», 2003. - 360 s.

3. Khomenko O. Osoblyvosti marketynhovoho tsinoutvorennya na rynku osvitnikh posluh / O. Khomenko // Visnyk Kyyivs'koho natsional'noho universytetu tekhnolohiy ta dyzaynu. Seriya "Ekonomika i vyshcha osvita". 2015. - № 5 (91). - C. 34-39.

4. Tyelyetova S. H. Pedahohichnyy marketynh u diyal'nosti navchal'nykh zakladiv / Tyelyetova S. H., Tyelyetov O. S. // Marketynh i menedzhment innovatsiy. - 2011. - № 3, T. 2. - S. 117-124.

5. Velykyy tlumachnyy slovnyk suchasnoyi ukrayins'koyi movy / Uklad. i holov. red. V. T. Busel. - K.: Irpin': VTF „Perun”, 2003. - 1440 s.

6. Statystyka rynka tovarov y usluh: Uchebnyk. - 2-e yzd. perab. y dop./ Y. K. Belyaevskyy, H. D. Kulahyna, L. A. Danchenok y dr.; Pod red. Y. K. Belyaevskoho. - M.: Fynansy y statystyka, 2002.-656 s.

7. Kotler F. Osnovy marketynha: Per. s anhl./ Obshch. red. y vstup. st. E.M. Pen'kovoy.- M.: Prohress, 1990.-736 s.

8. Deyneha, O. V. Do pytannya pro henezys osnovnykh definitsiy iz marketynhovoyi tovarnoyi polityky / O. V. Deyneha, I. O. Deyneha // Visnyk 
natsional'noho universytetu "L'vivs'ka politekhnika". Seriya: «Lohistyka». 2004. - № 499. - S. 31-36.

9. Vorobyova $O$. The influence of globalization processes on higher education development [Elektronnyy resurs]/ O. Vorobyova // Innovative solutions in modern science. - 2018. - № 2(21). - S. 74-85. - Rezhym dostupu: http://naukajournal.org/index.php/ISMSD/article/view/1477/1561 